\title{
Physiological Response and Haematological Profile of Reproductive Ewe Consuming Diet Supplemented with Black Tea Extract and Sunflower Seed Oil
}

\author{
Didid Diapari*, Widya Hermana, Febrina Prameswari, and Anuraga Jayanegara \\ Department of Nutrition and Feed Technology, Faculty of Animal Science, \\ Bogor Agricultural University, Jl. Agatis Kampus IPB Darmaga, Bogor 16680 \\ * Corresponding author e-mail: didid.diapari1962@gmail.com
}

\begin{abstract}
This study was aimed to examine the effect of black tea extract addition in diet containing $4 \%$ and $6 \%$ sunflower oil on ewe physiological responses and blood profiles from late pregnancy until early lactation. This study was designed using a $2 \times 2$ factorial completely randomized design with five replications on 20 latepregnant ewes. The first factor was two levels of sunflower seed oil ( $4 \%$ and $6 \%$ ) and the second factor was the levels of black tea extract addition (0 ppm and $500 \mathrm{ppm})$. Data were analyzed by using analysis of variance (ANOVA) and Duncan's multiple range test. Results showed that supplementation of sunflower seed oil and black tea extract had no effect on physiological responses and blood profiles of ewe during late pregnancy until early lactation except for erythrocyte numbers. Erythrocyte numbers were higher on $6 \%$ sunflower seed oil supplementation than that of $4 \%(\mathrm{P}<0.05)$. In conclusion, the addition of black tea extract in diets containing $4 \%$ and $6 \%$ sunflower seed oil limitedly affect physiological responses and blood profiles of the ewe.
\end{abstract}

Key words: black tea extract, blood profile, ewe, physiological response, sunflower seed oil

Abstrak. Penelitian ini bertujuan untuk menguji pengaruh ekstrak teh hitam pada konsentrasi 500 ppm dalam ransum yang mengandung $4 \%$ dan $6 \%$ minyak biji bunga matahari terhadap respon fisiologis dan profil darah domba fase reproduksi akhir kebuntingan hingga awal laktasi. Desain penelitian menggunakan rancangan acak lengkap pola faktorial $2 \times 2$ dengan faktor pertama terdiri dari 2 level minyak biji bunga matahari (4\% dan 6\%) dan faktor kedua terdiri dari 2 level ekstrak teh hitam (0 ppm dan 500 ppm) dengan 5 ulangan. Domba yang digunakan adalah domba periode akhir kebuntingan sebanyak 20 ekor (bobot badan awal $31.2 \pm 2.28 \mathrm{~kg}$ ). Peubah yang diamati meliputi respon fisiologis dan profil darah. Data diolah menggunakan analisis ragam dan uji jarak berganda Duncan. Hasil menunjukkan bahwa suplementasi minyak biji bunga matahari dan ekstrak teh hitam tidak memberikan pengaruh nyata terhadap respon fisiologis dan profil darah domba kecuali untuk jumlah eritrosit. Pemberian $6 \%$ minyak biji bunga matahari secara nyata meningkatkan jumlah eritrosit dibandingkan dengan pemberian $4 \%$ minyak $(P<0.05)$. Dapat disimpulkan bahwa penambahan 500 ppm ekstrak teh hitam dalam ransum mengandung $4 \%$ dan $6 \%$ minyak biji bunga matahari tidak mempengaruhi respon fisiologis dan profil darah domba.

Kata kunci: ekstrak teh hitam, domba, minyak biji bunga matahari, profil darah, respon fisiologis

\section{Introduction}

Indonesian local sheep have been known to have a genetic potential in the reproductive ability. Reproductive performance of the genetic factors will be expressed only if it is supported by conducive environmental factors such as the diet based on the nutrition requirement for reproductive ewe (Capper et al., 2006). Scaramuzzi et al. (2006) described that the reproductive performance is affected by quality and quantity of nutrients provided to pregnant ewes. Animals generally have four critical reproductive phases, i.e., during premating, early pregnancy, the final third of gestation, and early lactation; these phases require nutritious diet in order to support fetus growth and development. Pregnant ewe requires a high concentration of nutrients in the diet at similar quantity because consumption will be reduced due to the reduction of stomach volume as a result of the rapidly growing fetus (Munoz-Gutierrez et al. 2002).

Sunflower seed oil contains high fat, and it is expected to sufficiently supply the energy 
demand of ewe. Fat contains higher energy than that of carbohydrate or protein and produces lower heat increment. Low heat increment diet is apparently suitable for a tropical animal in order not to produce excessive heat. Thermoregulation process of continuous heat production is followed by heat release to the environment through skin and breath. This could be reflected in the measurement of physiological response parameters such as rectal temperature, respiration rate, heart rate, hematocrit, and heterophile to lymphocyte ratio.

Sunflower seed oil contains essential fatty acids such as linoleic acid $67.5 \%$ and oleic acid $18.7 \%$. Diet containing unsaturated fatty acids could improve the fertility of ruminants (Cerri et al., 2009) but it is prone to oxidation and thus should be accompanied by antioxidants for protecting them from oxidation (Fremont et al., 1999). Antioxidant is defined as a compound that could prevent oxidative reactions of lipids from free radicals (Damayanthi et al., 2004). Antioxidant activity in tea results from polyphenol (Gardner et al., 2007). Black tea contains natural antioxidants, i.e. polyphenol (119.0-178.8 $\mathrm{mg} \mathrm{g}^{-1}$ ) and theaflavin (9.7-13.7 mg $\left.\mathrm{g}^{-1}\right)$ to prevent peroxidation of unsaturated fatty acids in cell membrane phospholipids (Bhuyan et al., 2013).

The aim of this study was to examine the effect of black tea extract addition in diet containing $4 \%$ and $6 \%$ sunflower seed oil on the physiological responses of late pregnancy to early lactation ewe.

\section{Materials and Methods}

\section{Animal and experimental diet}

Twenty local sheep in late pregnancy to early lactation with an average body weight of $31.2 \pm$
$2.28 \mathrm{~kg}$ were used in this study. The sheep were randomly distributed into individual cages. Maintenance of ewe was performed since late pregnancy until three weeks after giving birth. Temperature and humidity in the animal house were measured three times a day at $06.30 \mathrm{am}$, 12:30 pm, and 17:30 pm. Total mixed ration of grass and concentrate (30:70) was used as the experimental diet. The grass used in this study was Brachiara humidicola. The concentrate was composed of cassava, coconut meal, soybean meal, premix, salt, $\mathrm{CaCO}_{3}$, sunflower seed oil and black tea extract. Extraction of black tea was conducted through maceration process of black tea powder dissolved in $70 \%$ ethanol with the ratio of ethanol, and black tea powder was 2:1. The mixture was allowed to stand for 24 hours and stirred every eight hours. The mixture was then filtered using filter paper and the filtrate was evaporated to obtain black tea extract. Black tea extract was mixed with tapioca flour with a proportion between tea extract and starch was 1:3.

This study employed a $2 \times 2$ factorial design based on a completely randomized design with 5 replications. First factor was 2 levels of sunflower seed oil supplementation $(4 \%$ and $6 \%)$ and the second was 2 levels of black tea extract addition ( $0 \mathrm{ppm}$ and $500 \mathrm{ppm}$ ). The treatment combinations were: M4T0 $(0 \mathrm{ppm}$ black tea extract $+4 \%$ sunflower seed oil), M4T500 (500 ppm black tea extract $+4 \%$ sunflower seed oil), M6T0 (500 ppm black tea extract $+6 \%$ sunflower seed oil), M6T500 (500 ppm black tea extract $+6 \%$ sunflower seed oil). Nutrient content of the experimental diets is presented in Table 1. 
Table 1. Nutrient content of experimental diet (\%DM)

\begin{tabular}{ccccc}
\hline \multirow{2}{*}{ Nutrient } & \multicolumn{3}{c}{ Diet } \\
\cline { 2 - 5 } & M4T0 & M4T500 & M6T0 & M6T500 \\
\hline DM (\%) & 64.5 & 68.4 & 69.2 & 69.2 \\
Ash (\%) & 9.0 & 9.2 & 9.3 & 7.9 \\
CP (\%) & 15.2 & 14.8 & 15.1 & 15.4 \\
EE (\%) & 8.1 & 7.9 & 10.4 & 10.6 \\
CF (\%) & 19.3 & 18.7 & 18.6 & 18.5 \\
NFE (\%) & 48.4 & 49.4 & 46.6 & 47.6 \\
TDN (\%) & 71.5 & 71.9 & 72.6 & 74.1 \\
\hline
\end{tabular}

M4T0: $4 \%$ oil + 0 ppm black tea extract, M4T500: $4 \%$ oil + 500 ppm black tea extract, M6T0: $6 \%$ oil + 0 ppm black tea extract, M6T500: $6 \%$ oil +500 ppm black tea extract.

DM: dry matter, CP: crude protein, EE: ether extract, CF: crude fiber, NFE: nitrogen free extract, TDN: total digestible nutrient.

\section{Physiological response}

Parameters measured on physiological responses were respiration rate, heart rate and rectal temperature. Duplo measurement of respiration rate, heart rate, and rectal temperature were determined every week during the experimental period from late pregnancy until early lactation. The respiration rate was measured by placing the palms on the nose and count the breaths for 1 minute using a stopwatch and counter. Heart rate was measured by placing a stethoscope on the left chest while ewe was in standing position and count rate for 1 minute. Rectal temperature was measured by inserting a digital body thermometer into the rectum.

\section{Haematological profile}

Blood sampling was performed at the end of pregnancy period. An amount of $3 \mathrm{ml}$ blood was drawn from the jugular vein of ewe using a sterile syringe, inserted into the tube with EDTA, and then taken to the laboratory for analysis. For hemoglobin determination, sahli tube was filled with $\mathrm{HCl} 0.1 \mathrm{~N}$, then filled with $0.1 \mathrm{~mL}$ of blood until brown hematin acid formed. Distilled water was added until the color looked as the standard color. Blood level in the tube indicated the amount of hemoglobin in $100 \mathrm{~mL} / \mathrm{g}$ blood. Hematocrit determination was performed by the microhematocrit method. Microcapiler pipe was filled with blood (about $4 / 5$ part of the pipe volume) and then closed with stopper and centrifuged for 5 minutes. Hematocrit value was presented as erythrocyte volume percentage (\%) read with microhematocrit reader.

For measuring number of red blood cells (erythrocytes) and white blood cells (leukocytes), blood sample was smoked using an erythrocyte pipette for red blood cells and leukocyte pipette for white blood cells, diluted with Hayem solution to the mark 101 for erythrocytes and diluted with Turk solution up to the mark 11 for leukocytes, and then homogenized. A drop of blood solution was dripped into the counting chamber covered with cover glass then observed under a microscope. Number of erythrocytes was calculated by looking at 25 boxes and observe the top corner right box, top left corner, middle, bottom right corner, and bottom left corner. Erythrocyte per $\mathrm{mm}^{3}$ was calculated by summing erythrocytes that counted in 5 small boxes and multiplied by $10^{4}$. Number of leukocytes was counted in 16 small boxes and observed 4 boxes on the top right corner, top left corner, bottom right corner, and bottom left corner. Leukocyte that counted in 16 squares was multiplied by 50 . Leukocyte differentiation was calculated on $100 \times 10$ microscope magnification. Leukocyte 
differentiation was made with 2 object glasses with the dropped blood then dried in the air, submerged in methanol solution for 5 minutes, and submerged in Giemsa solution for 30 minutes then washed. The number of lymphocytes, neutrophils, monocytes, and eosinophils counted in a zigzag up to a total of 100 items under the microscope. The percentage of each leukocyte derived from the number of each leukocyte differentiation was divided by the total number of leukocytes then multiplied by $100 \%$.

\section{Data analysis}

Data were processed using analysis of variance (ANOVA) and the continued with Duncan's multiple range test when the ANOVA result showed significance at $P<0.05$. Statistical analysis was performed by employing SPSS software version 20.

\section{Results and Discussion}

\section{Environmental condition}

Research location had fluctuation temperature and humidity from morning until evening. Ambient temperature observed in the morning, day and evening ranged between $24.1-31.0^{\circ} \mathrm{C}$ with the humidity of $70-89 \%$ (Table 2). Comfort zone of tropical sheep typically ranges between $22-31^{\circ} \mathrm{C}$ (Subronto, 2003). Apparently the average temperature in the animal house was in the range of comfort zone and therefore suitable for ewe maintenance. Meanwhile, optimum humidity for sheep is less than $75 \%$ (Subronto, 2003). The average of the highest humidity in the morning (89\%) exceeded the optimum humidity for sheep. This can be caused by a lack of air circulation inside the animal house so that water vapor is accumulated. A very high humidity is harmful since it may lead to slow and limited evaporation of water and potentially disturb animal thermoregulation system (Yani and Purwanto, 2006).
Table 2. Temperature and humidity during the experimental period

\begin{tabular}{lcc}
\hline Time & Temperature $\left({ }^{\circ} \mathrm{C}\right)$ & Humidity $(\%)$ \\
\hline Morning & $24 \pm 1.26$ & $89 \pm 4.33$ \\
Noon & $31 \pm 1.51$ & $72 \pm 8.99$ \\
Evening & $30 \pm 1.78$ & $71 \pm 8.32$ \\
\hline Average & $28.3 \pm 0.26$ & $77.3 \pm 2.51$ \\
\hline
\end{tabular}

\section{Physiological response}

Neither sunflower seed oil nor black tea extract affected the respiratory rate of late pregnancy to early lactation ewe (Table 3). Respiratory rate during the late period of pregnancy to early lactation ewe was higher than the normal range of ewe in the tropics according to Suprayogi and Astuti (2006). Respiratory rate in late pregnancy period was different from the early lactation period. Ewe during late pregnancy period does not consume diet as much as during lactating period due to the limited capacity of digestive organs with the fetus inside. Lactating animals consume the highest dry matter intake among other reproductive phases to produce milk and energy reserves for preparing the next breeding season. Under such condition, higher oxygen intake is needed to run body metabolism during lactation period than during pregnancy period. Increased respiratory rate reflected heat quickly passed through blood to the body in order to help animals released body heat for balanced body temperature.

Supplementation of sunflower seed oil and black tea extract did not affect the heart rate of late pregnancy to early lactation ewe (Table 4). The heart rate of ewe in late pregnancy period was within a normal range according to Subronto (2003), i.e., 70-90 times $\mathrm{min}^{-1}$. Black tea extract containing polyphenol is allegedly capable of improving blood circulation in order to maintain normal heart function. Provision of oil in diet could reduce body heat production so that the animals could improve their thermoregulation ability with lower heart rate. 
Heart rate of ewe during early lactation was above normal range, higher in comparison to late pregnancy period. It is apparently associated with the increase of respiration rate during early lactation as compared with late pregnancy. An increase of respiration frequency may lead to an increase of heart rate since respiration muscles need more supply of oxygen and nutrients, and thus the heart pumped the blood faster.

An Addition of black tea extract and sunflower seed oil had no effect on rectal temperature of ewe during late pregnancy until early lactation (Table 5). Rectal temperature of ewe during late pregnancy to early lactation is still within the normal range according to Subronto (2003), i.e. between $38-40^{\circ} \mathrm{C}$. It seems that heat exposure to animal is already happened for a long time so that animal could adapt in balancing body heat production with the release of body heat to the environment. The normal rectal temperature may also occur as result of feeding the fat from sunflower seed oil with lower heat increment than that of protein and carbohydrate so that the animals were not constrained in releasing body heat.

Table 3. Respiratory rate (times/min) of ewe fed with experimental diet

\begin{tabular}{llccc}
\hline & & M4 & M6 & Average \\
\hline \multirow{3}{*}{ Late Pregnancy } & T0 & $50 \pm 4.17$ & $54 \pm 13.70$ & $52 \pm 8.93$ \\
& T500 & $51 \pm 8.03$ & $52 \pm 14.11$ & $51.5 \pm 11.07$ \\
\cline { 2 - 5 } & Average & $50.5 \pm 6.1$ & $53 \pm 13.90$ & $51.75 \pm 10$ \\
\hline \multirow{3}{*}{ Early Lactation } & T0 & $65 \pm 7.13$ & $58 \pm 5.40$ & $61.5 \pm 6.26$ \\
& T500 & $61 \pm 12.28$ & $61 \pm 9.40$ & $61 \pm 10.84$ \\
\cline { 2 - 5 } & Average & $63 \pm 9.70$ & $59.5 \pm 7.4$ & $61.25 \pm 8.55$ \\
\hline
\end{tabular}

T0: addition of 0 ppm black tea extract, T500: addition of 500 ppm black tea extract, M4: addition of sunflower seed oil $4 \%$, M6: addition of sunflower seed oil $6 \%$.

Table 4. Heart rate (times/min) of ewe fed with experimental diet

\begin{tabular}{llccc}
\hline & & M4 & M6 & Average \\
\hline \multirow{3}{*}{ Late Pregnancy } & T0 & $84 \pm 8.23$ & $84 \pm 6.36$ & $84 \pm 7.29$ \\
& T500 & $85 \pm 11.65$ & $82 \pm 7.17$ & $83.5 \pm 9.41$ \\
\cline { 2 - 5 } & Average & $84.5 \pm 9.94$ & $83 \pm 6.76$ & $83.75 \pm 8.35$ \\
\hline \multirow{3}{*}{ Early Lactation } & T0 & $102 \pm 5.11$ & $104 \pm 4.84$ & $103 \pm 4.97$ \\
& T500 & $101 \pm 11.5$ & $102 \pm 6.25$ & $101.5 \pm 8.87$ \\
\cline { 2 - 5 } & Average & $101.5 \pm 8.30$ & $103 \pm 5.54$ & $102.25 \pm 6.92$ \\
\hline
\end{tabular}

T0: addition of 0 ppm black tea extract, T500: addition of 500 ppm black tea extract, M4: addition of sunflower seed oil $4 \%$, M6: addition of sunflower seed oil $6 \%$.

Table 5. Rectal temperature $\left({ }^{\circ} \mathrm{C}\right)$ of ewe fed with experimental diet

\begin{tabular}{llccc}
\hline & & M4 & M6 & Average \\
\hline \multirow{3}{*}{ Late Pregnancy } & T0 & $39.0 \pm 0.21$ & $38.9 \pm 0.30$ & $38.95 \pm 0.25$ \\
& T500 & $38.9 \pm 0.19$ & $38.9 \pm 0.14$ & $38.9 \pm 0.16$ \\
\cline { 2 - 5 } & Average & $38.95 \pm 0.20$ & $38.9 \pm 0.22$ & $38.92 \pm 0.20$ \\
\hline \multirow{3}{*}{ Early Lactation } & T0 & $38.8 \pm 0.15$ & $38.9 \pm 0.33$ & $38.85 \pm 0.24$ \\
& T500 & $38.7 \pm 0.23$ & $38.8 \pm 0.20$ & $38.75 \pm 0.21$ \\
\cline { 2 - 5 } & Average & $38.75 \pm 0.19$ & $38.5 \pm 0.26$ & $38.80 \pm 0.22$ \\
\hline
\end{tabular}

T0: addition of 0 ppm black tea extract, T500: addition of 500 ppm black tea extract, M4: addition of sunflower seed oil $4 \%$, M6: addition of sunflower seed oil $6 \%$. 


\section{Blood profile}

Generally, addition of black tea extract and sunflower seed oil in diet did not affect blood of ewe except for number of erythrocytes (Table $6)$. Concentrate with $6 \%$ sunflower seed oil showed higher erythrocytes number compared with concentrate with $4 \%$ sunflower seed oil $(P<0.05)$. This result suggested that higher amount of oil in diet could increase number of erythrocytes. Essential fatty acids present in oil are part of lymphoid tissue that maintain immune system function by forming prostaglandin. The function of prostaglandin hormone is to repair cell membrane, including the membrane of red blood cells and thus could increase the number of erythrocytes (Fritsche et al., 1992)

Table 6. Haematological profile of ewe fed with experimental diet

\begin{tabular}{|c|c|c|c|c|c|}
\hline Parameter & Normal * & & TO & T500 & Average \\
\hline \multirow{3}{*}{ Hematocrit (\%) } & \multirow{3}{*}{$27-45$} & M4 & $29.3 \pm 1.52$ & $31.7 \pm 2.08$ & $30.5 \pm 1.80$ \\
\hline & & M6 & $30.3 \pm 1.52$ & $32.3 \pm 2.51$ & $31.3 \pm 2.01$ \\
\hline & & Average & $29.8 \pm 1.52$ & $32.0 \pm 2.29$ & $30.9 \pm 1.90$ \\
\hline \multirow{3}{*}{$\begin{array}{l}\text { Hemoglobin } \\
\text { (g/dl) }\end{array}$} & \multirow{3}{*}{$9-15$} & M4 & $9.36 \pm 1.18$ & $9.46 \pm 0.80$ & $9.41 \pm 0.99$ \\
\hline & & M6 & $8.75 \pm 0.66$ & $9.13 \pm 0.23$ & $8.94 \pm 0.44$ \\
\hline & & Average & $9.05 \pm 0.92$ & $9.29 \pm 0.51$ & $9.17 \pm 0.71$ \\
\hline \multirow{3}{*}{$\begin{array}{l}\text { Eryhtrocytes } \\
\left(\text { million } / \mathrm{mm}^{3} \text { ) }\right.\end{array}$} & \multirow{3}{*}{$9-15$} & M4 & $7.40 \pm 0.61$ & $8.61 \pm 0.77$ & $8.00 \pm 0.69^{a}$ \\
\hline & & M6 & $10.04 \pm 0.69$ & $9.45 \pm 1.11$ & $9.74 \pm 0.90^{b}$ \\
\hline & & Average & $8.72 \pm 0.65$ & $9.03 \pm 0.94$ & $8.87 \pm 0.79$ \\
\hline \multirow{3}{*}{$\begin{array}{l}\text { Leucocytes } \\
\text { (thousands } / \mathrm{mm}^{3} \text { ) }\end{array}$} & \multirow{3}{*}{$8-12$} & M4 & $8.01 \pm 0.21$ & $9.10 \pm 1.65$ & $8.55 \pm 0.93$ \\
\hline & & M6 & $9.02 \pm 0.45$ & $10.25 \pm 0.35$ & $9.63 \pm 0.40$ \\
\hline & & Average & $8.51 \pm 0.33$ & $9.67 \pm 1.00$ & $9.09 \pm 0.66$ \\
\hline \multicolumn{6}{|l|}{ Leukocyte Differentiation } \\
\hline \multirow{3}{*}{ Lymphocytes (\%) } & \multirow{3}{*}{$50-70$} & M4 & $57.7 \pm 2.88$ & $58.0 \pm 4.00$ & $57.8 \pm 3.44$ \\
\hline & & M6 & $56.7 \pm 3.21$ & $58.0 \pm 7.00$ & $57.3 \pm 5.10$ \\
\hline & & Average & $57.2 \pm 3.04$ & $58.0 \pm 5.50$ & $57.6 \pm 4.27$ \\
\hline \multirow{3}{*}{ Neutrophils (\%) } & \multirow{3}{*}{$30-48$} & M4 & $37.0 \pm 1.00$ & $34.0 \pm 4.35$ & $35.5 \pm 2.67$ \\
\hline & & M6 & $38.3 \pm 2.08$ & $33.3 \pm 4.50$ & $35.8 \pm 3.29$ \\
\hline & & Average & $37.7 \pm 1.54$ & $33.7 \pm 4.42$ & $35.7 \pm 5.96$ \\
\hline \multirow{3}{*}{ Basophils (\%) } & \multirow{3}{*}{$0-3$} & M4 & $1.33 \pm 1.15$ & $2.00 \pm 0.01$ & $1.66 \pm 1.15$ \\
\hline & & M6 & $1.67 \pm 1.15$ & $3.00 \pm 1.00$ & $2.33 \pm 1.07$ \\
\hline & & Average & $1.50 \pm 1.15$ & $2.50 \pm 0.50$ & $1.99 \pm 1.11$ \\
\hline \multirow{3}{*}{ Monocytes (\%) } & \multirow{3}{*}{$0-4$} & M4 & $1.67 \pm 1.15$ & $2.67 \pm 0.57$ & $2.16 \pm 1.09$ \\
\hline & & M6 & $2.00 \pm 1.73$ & $3.33 \pm 0.57$ & $2.66 \pm 1.15$ \\
\hline & & Average & $1.83 \pm 1.44$ & $3.00 \pm 0.57$ & $2.40 \pm 1.00$ \\
\hline \multirow{3}{*}{ Eusinophils (\%) } & \multirow{3}{*}{$1-8$} & M4 & $2.33 \pm 0.57$ & $3.33 \pm 1.15$ & $2.83 \pm 0.86$ \\
\hline & & M6 & $1.33 \pm 0.57$ & $2.33 \pm 1.52$ & $1.83 \pm 1.04$ \\
\hline & & Average & $1.83 \pm 0.57$ & $2.83 \pm 1.33$ & $2.33 \pm 0.95$ \\
\hline \multirow{3}{*}{$\begin{array}{l}\text { Neutrophils } \\
\text { /Lymphocytes }\end{array}$} & \multirow{3}{*}{0.5} & M4 & $0.64 \pm 0.04$ & $0.59 \pm 0.11$ & $0.61 \pm 0.07$ \\
\hline & & M6 & $0.67 \pm 0.07$ & $0.58 \pm 0.15$ & $0.62 \pm 0.11$ \\
\hline & & Average & $0.65 \pm 0.05$ & $0.58 \pm 0.13$ & $0.61 \pm 0.09$ \\
\hline
\end{tabular}

* Normal value by Schalm (2010).

T0: addition of 0 ppm black tea extract, T500: addition of 500 ppm black tea extract, M4: addition of sunflower seed oil $4 \%$, M6: addition of sunflower seed oil $6 \%$.

Different superscripts in the same column are significantly different at $P<0.05$. 
Ewe hemoglobin value in this experiment was within the normal range according to Schalm (2010), apparently due to adequate Fe supply such as from sunflower seed oil that contains high Fe, i.e. $49.66 \mathrm{mg} \mathrm{kg}^{-1}$ (Özcan, 2006). Ewe hematocrit values were also within the normal range, comparable to the hemoglobin and red blood cell count reported by Mawati et al. (2004). This may reflect that ewe has been adapted under tropical condition. Number of leucocytes as well as leukocyte differentiation for all treatments were within the normal range, indicating that immune system was not compromised by feeding treatment.

Neutrophil to lymphocyte ratio is an indicator of animal response to environmental change (Maheswari, 2008). High ratio of neutrophil to lymphocyte indicates that animals experiencing stress (Kannan, 2000). Stress produces glucocorticoid hormones that may disturb immune cells. Glucocorticoid disturbed the cytokines production that necessary for immune responses (Mashaly et al., 2004). Stress may lead to leukocytosis that is caused by increasing neutrophil from glucocorticoids induced and release of neutrophil reserves in the marrow bone (Sugito and Delima, 2009). Standard value for neutrophil to lymphocyte ratio in sheep is 0.5 (Schalm, 2010). Data in the present study showed that ewe neutrophil to lymphocyte ratio were above normal for all treatments. This could be due to animal exposure to fluctuating temperature, causing stress of the animals.

\section{Conclusions}

Supplementation of black tea extract and sunflower seed oil did not affect physiological responses and majority of blood parameters of ewe during late pregnancy until early lactation. Supplementation of $6 \%$ sunflower seed oil in diet increased erythrocytes of ewe as compared with 4\% sunflower seed oil.

\section{References}

Bhuyan, L. P., Sabhapondit, S., Baruah, B. D., Bordoloi, C., Gogoi, R., Bhattacharyya, P. 2013. Polyphenolic compounds and antioxidant activity of CTC black tea of North-East India. Food Chem. 141:37443751.

Capper, J. L., Robert, G., Wilkinson, Alexander, M., Mackenzie, Sinclair, L.A. 2006. Polyunsaturated fatty acid supplementation during pregnancy alters neonatal behavior in sheep, nutrient physiology, metabolism, and nutrient-nutrient interactions. J. Nutr. 136:397-403.

Cerri, R. L. A., Juchem, S. O., Chebel, R. C., Rutigliano, H. M., Bruno, R. G. S., Galvao, K. N., Thatcher,r W. W., Santos, J. E. P. 2009. Effect of fat source differing in fatty acid profile on metabolic parameters, fertilization, and embryo quality in high producing dairy cows. J. Dairy Sci. 92:15291531.

Damayanthi, E., Syarief, H., Muchtadi, D., Wijaya, H., Zakaria, F. R., Damardjati, D. S. 2004. Aktivitas antioksidan minyak bekatul padi awet dan fraksinya secara in vitro. J. Teknol. Industri Pangan 15:11-19.

Fremont, L., Belguendouz, L., Delpal, S. 1999. Antioxidant activity of resveratrol and alcohol-free wine polyphenols related to LDL oxidation and polyunsaturated fatty acids. J. Life Sci. 64:2511-2521.

Fritsche, K. L., Cassity, N. A., Huang, S. C. 1992. Dietary (n-3) fatty acid and vitamin E interactions in rats: Effect on vitamin $E$ status, immune cell prostaglandin $E$ production and primary antibody response. J. Nutr. 122:1009-1018.

Gardner, E. J., Ruxton, C. H. S., Leeds, A. R. 2007. Black tea- helpful or harmful? A review of the evidence. Eur. J. Clin. Nutr. 61:3-18.

Kannan, T. H. 2000. Transportation of goats: Effects on physiological stress responses and live weight loss. J. Anim. Sci. 78:1450 - 1457. 
Maheswari, H. 2008. Rasio netrofil limfosit sebagai indikator stres pada owa Jawa di Tempat Penangkaran. J Unair. 7 (2): 75-86.

Mashaly, M. M., Hendricks, G. L., Kalama, M. A., Gehad, A. E., Abbas, A. O., Patterson, P. H. 2004. Effect of heat stress on production parameters and immune responses of commercial laying hens. Poult. Sci. 83:889894.

Mawati, S., Warsino, Purnomoadi, A. 2004. Pengaruh pemberian zat phytogenic pada berbagai tingkat terhadap kadar hematokrit, kadar urea darah dan kadar glukosa darah pada domba lokal jantan. J Pengembangan Peternakan Tropis Special Edition: 115-120.

Munoz-Gutierrez, M., Blache, D., Martin, G. B., Scaramuzzi, R. J. 2002. Folliculogenesis and ovarian expression of mRNA encoding aromatase in anoestrous sheep after 5 days of glucose or glucosamine infusion or supplementary lupin feeding. J. Soc. Reprod. Fertility. 124:721-731.

Özcan, M. M. 2006. Determination of the mineral compositions of some selected oilbearing seeds and kernels using Inductively Coupled Plasma Atomic Emission Spectrometry (ICP-AES). Grasas Y Aceites. 57:211-218.
Scaramuzzi, R. J., Campbell, B. C., Downing, J. A., Kendall, N. R., Kalid, M., MunozGutierrez, M., Somchit, A. 2006. A review of the effects of supplementary nutrition in the ewe on the concentrations of reproductive and metabolic hormones and the mechanisms that regulate folliculogenesis and ovulation rate. J. Reprod. Nutr. Dev. 46:339-354.

Schalm, O. W. 2010. Veterinary Hematology. $6^{\text {th }}$ Edition. Ames (US): Blackwell Publishing Ltd.

Subronto. 2003. IImu Penyakit Ternak Mamalia. Yogyakarta (ID): Gadjah Mada University Press.

Sugito, Delima, M. 2009. Effect of heat stress on body weight gain, heterophile-lymphocyte ratio and body temperature in broiler. J. Ked. Hewan 3:218-226.

Suprayogi, A., Astuti, D. A. 2006. Physiological status of indoor sheep in the tropical rainforest (HPGW) environment. J. Agric. Rural Dev. Trop. Subtrop. 88:1-5.

Yani, A., Purwanto, B. P. 2006. Pengaruh iklim mikro terhadap respons fisiologis sapi peranakan friesien Holland dan modifikasi lingkungan untuk meningkatkan produktivitasnya. Med. Pet. 29: 35-46. 